\title{
Changes in teat-end hyperkeratosis after installation of an individual quarter pulsation milking system
}

\author{
A. E. Sterrett, ${ }^{\star}$ C. L. Wood, † K. J. McQuerry, $†$ and J. M. Bewley ${ }^{\star 1}$ \\ ${ }^{*}$ Department of Animal and Food Sciences, and \\ †Department of Statistics, University of Kentucky, Lexington 40546
}

\begin{abstract}
The objective of this study was to examine changes in teat-end hyperkeratosis (HK) in a herd transitioning from a standard pulsation milking system to an individual quarter pulsation milking system. The Milpro P4C (Milkline, Gariga di Podenzano, Italy) system stops milking individual quarters using an individual quarter pulsation milking system with 4 independent pulsation channels per cluster instead of 2. Teat-end HK was evaluated immediately after cluster removal using a scoring system where $\mathrm{N}$ signifies no ring; $\mathrm{S}$ signifies a smooth, raised ring; $\mathrm{R}$ signifies a rough ring; and VR signifies a very rough ring. Scorings were classified for 69 cows (48 Holstein, 12 crossbred, and 9 Jersey) on 5 dates relative to installation of the Milpro $\mathrm{P} 4 \mathrm{C}$ system on April 28, 2011, as follows: April 7 (PRE1); April 21 (PRE2), May 12 (POST1), May 26 (POST2), and June 9 (POST3). Hyperkeratosis classifications were converted to numerical scores as follows: $\mathrm{N}=1, \mathrm{~S}=$ $2, \mathrm{R}=3$, and $\mathrm{VR}=4$. The MIXED procedure of SAS (SAS Institute Inc., Cary, NC) was used to evaluate fixed effects of age, breed, parity, teat position, and all interactions on teat-end HK score with variables repeated by scoring with cow within breed as subject. The effects of teat position and scoring $\times$ breed on teat-end HK score were significant. Holstein HK scores improved from PRE2 to POST3 (1.64 \pm 0.09 and 1.42 \pm 0.10 , respectively), POST1 to POST3 $(1.59 \pm 0.10$ and $1.41 \pm 0.10$, respectively), and POST2 to POST3 $(1.53 \pm 0.10$ and $1.42 \pm 0.10$, respectively). Crossbred HK scores did not differ among scorings. Jersey HK scores worsened from POST1 to POST3 $(1.32 \pm 0.21$ and $1.63 \pm 0.22$, respectively). For all cows included in the final analysis, right front and left front HK scores were higher than right rear and left rear HK scores $(1.58 \pm 0.09,1.62 \pm 0.09,1.37 \pm 0.09$, and $1.36 \pm$ 0.09 , respectively). However, a significant decrease in teat-end HK scores for Holsteins did occur from PRE1
\end{abstract}

Received August 19, 2012.

Accepted March 6, 2013.

${ }^{1}$ Corresponding author: jbewley@uky.edu to PRE2 (1.75 \pm 0.10 and $1.63 \pm 0.10$, respectively) and may represent biological variation in teat-end HK over time unrelated to installation of the individual quarter pulsation system. Individual quarter pulsation milking systems may prevent overmilking and reduce HK in Holstein cows. Further research is warranted to understand the breed differences observed in this study. Key words: hyperkeratosis, teat end, individual quarter pulsation

\section{INTRODUCTION}

The teat end or orifice is an important first line of defense in protecting the udder from invasion of mastitis pathogens (Gleeson et al., 2004). The maintenance of healthy teat skin and teat ends is a key component of an effective mastitis prevention program (Mein et al., 2001). After repeated milkings, a callous ring around the teat orifice may develop, termed hyperkeratosis (HK; Neijenhuis et al., 2001b). Hyperkeratosis refers to a histological response to chronic stimulation and is marked by an increase in the thickness of the stratum corneum or the keratin layer of the teat end (Breen et al., 2009).

Overmilking occurs when the milk flow to the teat cistern is less than the flow out of the teat canal, and it can cause or exacerbate teat-end HK. Rasmussen (2004) explained that breeding for high milk yield has produced cows with a higher percentage of cisternal capacity within the udder, reducing udder emptying functionality. Mechanical forces exerted by vacuum and the moving liner during machine milking affect teat-end HK incidence (Neijenhuis et al., 2000, 2001b). Rasmussen (1999) proposed that the last $0.5 \mathrm{~min}$ of milking was the most sensitive period for developing HK because the teats were almost empty. Other factors not examined in this study that affect teat-end HK include teat-end shape (Neijenhuis et al., 2000; Gleeson et al., 2004), genetic predisposition (Gleeson et al., 2004), seasonal weather conditions (Mein et al., 2001), and long unit-on times (Zucali et al., 2008). Teats with unit-on times $<4.30$ min were 0.29 times less likely to develop HK scores of $\mathbf{R}$ (rough ring) or 
VR (very rough ring) than teats with unit-on times $>5.30 \mathrm{~min}(P<0.01)$, citing more liner collapses as a possible cause of high HK scores. In the same study, teats starting with an HK classification of $\mathbf{N}$ (no ring) were 0.38 times less likely to be scored $\mathrm{R}$ and VR than teats starting with an HK classification of $\mathbf{S}$ (smooth, raised ring; $P<0.01$ ). Conversely, teats that started with an HK classification of R or VR were 24.2 times more likely to end with a classification of $\mathrm{R}$ or VR than teats starting the experiment with a classification of $\mathrm{S}$. The study results demonstrated the difficult recovery from severe HK (Zucali et al., 2008).

Dairy advisors associate more severe HK with increased clinical mastitis incidence (Neijenhuis et al., 2001a). In an 8-herd study, the odds of contracting Streptococcus uberis or Escherichia coli clinical mastitis increased significantly with increased HK (Breen et al., 2009). O'Shea (1987) proposed that changes to teat-end condition resulting from overmilking might increase the likelihood of bacterial penetration into the udder. Natzke et al. (1978) determined that more new infections occurred in cows when milking units were set at a fixed removal time of $12 \mathrm{~min}(40,27$, and 15 new infections for 3 experimental repetitions) compared with cows with milking units removed at the end of milk flow $(19,20$, and 12 new infections for 3 experimental repetitions). Natzke et al. (1978) concluded that overmilking may have contributed to higher mastitis infection rates, likely due to teat-end condition, but the differences in infection rates between the 2 groups were not significant $(P>0.05)$. Rasmussen $(1999,2004)$ explained that the reverse pressure gradient created when the vacuum in the teat cistern is higher than that beneath the teat end may allow for bacterial invasion of the teat cistern, making overmilking a culprit for increased bacterial colonization at the teat end. Each 1-unit increase in teat-end HK score increased the chances of intramammary infection by $30 \%$ in a study conducted by de Pinho Manzi et al. (2012). Hyperkeratosis scores were positively correlated with bacterial counts of the environmental pathogens Strep. uberis, E. coli, and other coliforms ( $\mathrm{r}>0.50, P$ $<0.01$ ), but not with Staphylococcus aureus (Paduch et al., 2012). Rough teat ends may provide a site for bacterial colonization because they may be more difficult to clean during premilking preparation (Zucali et al., 2008). However, Shearn and Hillerton (1996) failed to identify a significant relationship between SCC and degree of HK at the herd level.

Individual quarter pulsation milking systems may prevent overmilking and improve teat-end condition (Neijenhuis et al., 2000). Automated milking systems often incorporate individual quarter pulsation, but research on this feature in a conventional parlor is lack- ing. Automated milking systems have not been heavily adopted in the United States because of the availability of inexpensive labor relative to that in other countries (Jacobs and Siegford, 2012). The objective of this research was to examine changes in teat-end HK in a herd transitioning from a standard pulsation system to an individual quarter pulsation milking system.

\section{MATERIALS AND METHODS}

This study was conducted at the University of Kentucky Coldstream dairy from April to June 2011. Teatend HK was evaluated by the first author immediately after cluster removal using the scoring system outlined by Mein et al. (2001), where $\mathrm{N}$ indicates no ring; $\mathrm{S}$ indicates a smooth, raised ring; $\mathrm{R}$ indicates a rough ring; and VR indicates a very rough ring. Scoring periods were classified relative to installation of the Milpro P4C (Milkline, Gariga di Podenzano, Italy) system (April 28, 2011) as follows: April 7 (PRE1), April 21 (PRE2), May 12 (POST1), May 26 (POST2), and June 9 (POST3).

Ambient weather conditions were recorded at 1 -h intervals at the Lexington Bluegrass Airport (14.2 $\mathrm{km}$ from the study site). Temperature-humidity index (THI) was computed using the following formula $($ NOAA, 1976$):$ THI $=$ temperature $\left({ }^{\circ} \mathrm{F}\right)-[0.55-(0.55$ $\times$ relative humidity $/ 100)] \times$ temperature $\left.\left({ }^{\circ} \mathrm{F}\right)-58.8\right]$.

Cows were milked twice daily before and after installation of the new system. Milking routine before and after installation included forestripping, predipping, drying teats with individual paper towels, unit attachment, automatic takeoff, and postdipping. No changes were made to the milking routine after installation. The herd was divided into 2 balanced groups based on parity, breed, and size for a separate research project throughout the entire study period. Each group was milked in 1 of 2 double- 2 bypass parlors, located in the same building. High lines were used before and after installation. Vacuum pressure was adjusted to manufacturer recommendations after installation of the new system

Before installation, cows were milked using Surge Eclipse claws with 06 shells, 1st Choice triangular inflations, and Surge Omni cylinder detachers with optical sensors (GEA Farm Technologies Inc., Naperville, IL). The Milpro P4C (Milkline, Gariga di Podenzano, Italy) system, equipped with silicone liners, stops milking individual quarters based on flow rates, and has a unique individual quarter pulsation milking system with 4 pulsation channels instead of 2 . Pulsation ratio and frequency are variable and driven by the milk flow in the Milpro P4C system. As the flow increases, the length of the milking phase $(\mathrm{A}+\mathrm{B}$, where $\mathrm{A}$ is the opening phase and $\mathrm{B}$ is the milking phase) increases, whereas 
the duration of the rest phase $(\mathrm{C}+\mathrm{D}$, where $\mathrm{C}$ is the closing phase and $\mathrm{D}$ is the massage phase) is constant and the pulsation rate slows down. When milk flow is below $1.2 \mathrm{~kg} / \mathrm{min}$, the pulsation ratio is $60: 40$ and the pulsation rate is 60 pulses $/ \mathrm{min}$. The milking phase (A $+\mathrm{B}$ ) increases dynamically when milk flow is between 1.2 and $7.5 \mathrm{~kg} / \mathrm{min}$, whereas the rest phase remains at $400 \mathrm{~ms}$. Although the milking system used in this study detects individual quarter milk flow and stops milking individual quarters when low flow is detected, pulsation still occurs every $15 \mathrm{~s}$ and the liner remains in a massage phase between pulses. This process may reduce overmilking, acting on each quarter individually.

Teat-end HK classifications were evaluated for 109 cows during the study. Only cows with classifications available for the entire study period were included in the final analysis to ensure that HK data were available before installation and that each cow had the full length of time to experience the effects of the individual quarter pulsation milking system. Forty cows were removed, leaving 69 cows (48 Holstein, 12 crossbred, and 9 Jersey) in the final analysis. Teat-end HK classifications were converted to numerical values progressing from most desirable to least desirable as follows: $\mathrm{N}=$ $1, \mathrm{~S}=2, \mathrm{R}=3$, and $\mathrm{VR}=4$. When a given HK score differed from preceding and subsequent scores by more than \pm 1 , that score was removed from the data set to account for the subjectivity of the scoring system.

Score frequencies were calculated by scoring period using the FREQ procedure of SAS (version 9.3; SAS Institute, Inc., Cary, NC). The MIXED procedure of SAS was used to evaluate fixed effects of breed, parity, teat position, and all interactions on teat-end HK score. Variables were repeated by scoring with cow nested within breed as subject. All main effects were kept in each model regardless of significance level. Stepwise backward elimination was used to remove nonsignificant interactions $(P>0.05)$. Correlations between teats on the same cow were taken into account when calculating standard errors.

\section{RESULTS AND DISCUSSION}

Mean daily milk production, parity, DIM, and DHIAbased SCS for the herd were $34.31 \pm 9.92 \mathrm{~kg}, 2.30 \pm$ 1.24 lactations, $153.38 \pm 90.10 \mathrm{~d}$, and $1.66 \pm 1.24$, respectively. Average daily temperature-humidity indices were 63.66, 66.41, 60.83, 63.21, and 60.15 for PRE1, PRE2, POST1, POST2, and POST3 scoring periods, respectively; mean THI was 63.34 for the entire study period. Because ambient weather conditions were mild and stable during the study, the likelihood of weather influences on teat-end HK was negligible. The timing of changes in teat-end HK observed in this study was consistent with the 2 to 8 wk necessary for a change in teat HK described by Mein et al. (2001) and Gleeson et al. (2004).

The frequency of the more desirable teat-end condition classification $\mathrm{N}$ increased, after the installation of the individual quarter pulsation milking system, from 134 to 157 from PRE2 to POST3 (Table 1). The frequency of teat-end HK classification R decreased from $3.6 \%$ at PRE2 to $1.4 \%$ at POST3, whereas the frequency of teat-end HK classification VR remained constant throughout the study $(3.2 \%$ at PRE2, POST1, and POST3). This may be a reflection of teat-end shape, genetics, or the difficulty in recovering from severe teat-end HK, where teats classified as VR could only improve to a classification of $\mathrm{R}$, whereas classifications of $\mathrm{R}$ improved further.

Teat position and scoring period $\times$ breed had significant effects on teat-end HK score (Table 2; $P<$ 0.01). Scoring period, breed, and parity did not have significant effects on teat-end HK score $(P>0.05)$. The parity effect observed in this study was in contrast to results from Mein et al. (2001), who concluded that HK scores increased with parity, possibly as a result of udder and teat size changes with increasing parity. Seykora and McDaniel (1986) explained that teat length and diameter increased by approximately $10 \%$ from first to fourth lactations and udder depth increased by $20 \%$.

Table 1. Teat-end hyperkeratosis classification frequency by teat scoring period before and after the installation of an individual quarter pulsation milking system

\begin{tabular}{|c|c|c|c|c|c|}
\hline \multirow[b]{2}{*}{ Score $^{1}$} & \multicolumn{5}{|c|}{ Scoring period $^{2}$} \\
\hline & PRE1 & PRE2 & POST1 & POST2 & POST3 \\
\hline $\mathrm{N}$ & $60.9 \%(\mathrm{n}=134)$ & $60.9 \%(\mathrm{n}=134)$ & $65.9 \%(\mathrm{n}=145)$ & $67.3 \%(\mathrm{n}=148)$ & $71.4 \%(\mathrm{n}=157)$ \\
\hline $\mathrm{S}$ & $28.6 \%(\mathrm{n}=63)$ & $30.0 \%(\mathrm{n}=66)$ & $27.7 \%(\mathrm{n}=61)$ & $25.9 \%(\mathrm{n}=57)$ & $24.1 \%(\mathrm{n}=53)$ \\
\hline $\mathrm{R}$ & $3.6 \%(\mathrm{n}=8)$ & $5.9 \%(\mathrm{n}=13)$ & $3.2 \%(\mathrm{n}=7)$ & $4.5 \%(\mathrm{n}=10)$ & $1.4 \%(\mathrm{n}=3)$ \\
\hline VR & $6.8 \%(\mathrm{n}=15)$ & $3.2 \%(\mathrm{n}=7)$ & $3.2 \%(\mathrm{n}=7)$ & $2.3 \%(\mathrm{n}=5)$ & $3.2 \%(\mathrm{n}=7)$ \\
\hline
\end{tabular}


Table 2. Type III tests of fixed effects for teat-end hyperkeratosis score mixed model relative to the installation of an individual quarter pulsation milking system

\begin{tabular}{lcccc}
\hline Source & Numerator df & Denominator df & $F$-value & $P$-value \\
\hline Teat position $^{1}$ & 3 & 171 & 7.84 & $<0.01$ \\
Scoring period $^{2}$ & 4 & 264 & 0.33 & 0.86 \\
Breed $^{3}$ & 2 & 65 & 1.56 & 0.22 \\
Parity $^{4}$ & 1 & 65 & 0.01 & 0.91 \\
Scoring period $\times$ breed & 8 & 264 & 3.03 & $<0.01$ \\
\hline
\end{tabular}

${ }^{1}$ Teat position: left front, right front, left rear, right rear.

${ }^{2}$ Scoring period: PRE1 and PRE2 = teat-end condition observation periods using a standard pulsation milking system; POST1, POST2, and POST3 = teat-end condition observation periods following installation of an individual quarter pulsation milking system.

${ }^{3}$ Breed: Holstein, Jersey, or crossbred.

${ }^{4}$ Parity: 1 or $\geq 2$.

Holstein HK scores improved from PRE2 to POST3 (Table $3 ; 1.63 \pm 0.10$ and $1.42 \pm 0.10$, respectively, $P<0.01)$ and from POST2 to POST3 $(1.53 \pm 0.10$ and $1.42 \pm 0.10$, respectively, $P<0.05$ ). These results indicate an improvement in teat-end HK scores after the installation of an individual quarter pulsation milking system. However, a significant decrease in teat-end HK scores for Holsteins did occur from PRE1 to PRE2 $(1.75 \pm 0.10$ and $1.63 \pm 0.10$, respectively, $P=0.04)$ and may represent biological variation in teat-end HK over time unrelated to the installation of the individual quarter pulsation system.

Crossbred teat-end HK scores did not differ among scoring periods $(P>0.05)$. Jersey teat-end HK scores increased from POST1 to POST3 $(1.32 \pm 0.21$ and 1.63 \pm 0.21 , respectively, $P=0.05)$. Teat-end HK increased for Jersey cows and did not improve for crossbred cows, possibly reflecting differences in genetic predisposition or teat-end shape, which were not evaluated in this study. Teat-end shape was moderately to highly heritable in a study of 1,740 Holstein cows in 9 herds with heritability estimates of $0.54,0.44$, and 0.56 for first, second, and all lactations, respectively (Chrystal et al., 1999). Seykora and McDaniel (1985) reported similar heritability estimates. The same study explained that lesion score (where 1 represented a smooth, raised ring and 7 represented an ulcerated or raw-appearing orifice) decreased as teat-end shape score (using a continuous scale of 1 to 50 where each increment of 10 represented pointed, round, flat, disk, and inverted or cone-shaped teats, respectively) increased. However, teat-end shape is likely influenced by the environment and multiple genes (Chrystal et al., 1999). Within the Holstein breed in another study, teat-end shape did not vary greatly, with $90 \%$ of teats classified as cylindrical (Seykora and McDaniel, 1985). However, we are unaware of any studies comparing teat-end shape between multiple breeds so a direct comparison to the differences in teat-end HK found in this study is not possible. In this multibreed herd, liners and equipment settings were set for Holstein cows and may not be ideal for Jersey and crossbred cows. Differences between breeds could also be a result of the flow-dependent pulsation ratio and frequency in the new system, which could affect unit on-times. However, data on pulsation are not recorded within the system and was beyond the focus of the hypothesis to evaluate independently.

For all cows over all scoring periods, right front HK scores were higher than right rear or left rear HK scores $(1.58 \pm 0.20,1.37 \pm 0.15$, and $1.36 \pm 0.15$, respectively,

Table 3. Least squares means $( \pm \mathrm{SE})$ hyperkeratosis scores ${ }^{1}$ within teat scoring period relative to the installation of an individual quarter pulsation milking system

\begin{tabular}{lccccc}
\hline & \multicolumn{5}{c}{ Scoring period $^{2}$} \\
\cline { 2 - 5 } Breed & PRE1 & PRE2 & POST1 & POST2 & POST3 \\
\hline Holstein & $1.75 \pm 0.10^{\mathrm{a}}$ & $1.63 \pm 0.10^{\mathrm{a}}$ & $1.59 \pm 0.10^{\mathrm{b}}$ & $1.53 \pm 0.10^{\mathrm{b}}$ & $1.42 \pm 0.10^{\mathrm{c}}$ \\
Jersey & $1.40 \pm 0.21^{\mathrm{ab}}$ & $1.34 \pm 0.21^{\mathrm{ab}}$ & $1.32 \pm 0.21^{\mathrm{b}}$ & $1.43 \pm 0.21^{\mathrm{ab}}$ & $1.63 \pm 0.21^{\mathrm{a}}$ \\
Crossbred & $1.35 \pm 0.17^{\mathrm{a}}$ & $1.47 \pm 0.17^{\mathrm{a}}$ & $1.40 \pm 0.17^{\mathrm{a}}$ & $1.49 \pm 0.17^{\mathrm{a}}$ & $1.44 \pm 0.17^{\mathrm{a}}$ \\
\hline
\end{tabular}

${ }^{\mathrm{a}-\mathrm{c}}$ Least squares means within rows with different superscripts differ $(P<0.05)$.

${ }^{1}$ Where $1=$ no $\operatorname{ring}(\mathrm{N}) ; 2=$ a smooth, raised ring $(\mathrm{S}) ; 3=$ a rough ring $(\mathrm{R})$; and $4=$ a very rough $\operatorname{ring}(\mathrm{VR})$. ${ }^{2}$ Scoring period: PRE1 and PRE2 = teat-end condition observation periods using a standard pulsation milking system; POST1, POST2, and POST3 = teat-end condition observation periods following installation of an individual quarter pulsation milking system. 
Table 4. Least squares means $( \pm \mathrm{SE})$ hyperkeratosis $\operatorname{scores}^{1}$ in Holsteins by teat position relative to the installation of an individual quarter pulsation milking system

\begin{tabular}{|c|c|c|c|c|}
\hline \multirow{2}{*}{$\begin{array}{l}\text { Scoring } \\
\text { period }^{2}\end{array}$} & \multicolumn{4}{|c|}{ Teat position } \\
\hline & Left front & Left rear & Right front & Right rear \\
\hline PRE1 & $1.80 \pm 0.16^{\mathrm{ab}}$ & $1.52 \pm 0.16^{\mathrm{a}}$ & $1.83 \pm 0.16^{\mathrm{b}}$ & $1.46 \pm 0.16^{\mathrm{a}}$ \\
\hline PRE2 & $1.75 \pm 0.14^{\mathrm{a}}$ & $1.40 \pm 0.14^{\mathrm{b}}$ & $1.75 \pm 0.14^{\mathrm{a}}$ & $1.51 \pm 0.14^{\mathrm{ab}}$ \\
\hline POST1 & $1.82 \pm 0.15^{\mathrm{a}}$ & $1.61 \pm 0.15^{\mathrm{a}}$ & $1.62 \pm 0.15^{\mathrm{a}}$ & $1.49 \pm 0.15^{\mathrm{a}}$ \\
\hline POST2 & $1.64 \pm 0.14^{\mathrm{a}}$ & $1.48 \pm 0.14^{\mathrm{a}}$ & $1.58 \pm 0.14^{\mathrm{a}}$ & $1.59 \pm 0.14^{\mathrm{a}}$ \\
\hline POST3 & $1.53 \pm 0.11^{\mathrm{a}}$ & $1.34 \pm 0.11^{\mathrm{a}}$ & $1.40 \pm 0.11^{\mathrm{a}}$ & $1.30 \pm 0.11^{\mathrm{a}}$ \\
\hline All scorings & $1.71 \pm 0.09^{\mathrm{a}}$ & $1.45 \pm 0.08^{\mathrm{b}}$ & $1.63 \pm 0.09^{\mathrm{ab}}$ & $1.45 \pm 0.09^{\mathrm{b}}$ \\
\hline
\end{tabular}

$P<0.01)$, and left front HK scores were higher than right rear or left rear HK scores $(1.62 \pm 0.38,1.37$ \pm 0.15 , and $1.36 \pm 0.15$, respectively, $P<0.01)$. For Holstein cows only, teat-end HK scores were higher for right front than left rear and right rear HK scores in PRE1 (Table 4; $1.83 \pm 0.16,1.52 \pm 0.16$, and $1.46 \pm$ 0.16 , respectively, $P<0.04)$. Teat-end HK scores for Holstein cows were higher for left front and right front than left rear in PRE2 $(1.75 \pm 0.14,1.75 \pm 0.14$, and $1.40 \pm 0.14$, respectively, $P<0.01)$. Neijenhuis et al. (2000) reported similar results. Only $40 \%$ of milk resides in the front quarters, making them more susceptible to overmilking. No significant change between front and rear teat-end HK was observed after installation of the individual quarter pulsation milking system, and front teat HK scores improved more than rear teat HK scores over the study period. This result may indicate that individual quarter pulsation may stop milking front teats before rear teats when necessary, which would prevent the overmilking that results from the milk imbalance of the udder halves.

Although the improvement in HK shown in this study can be attributed to the individual quarter pulsation system, some changes may have resulted from the different inflations and the flow-dependent pulsation ratio and frequency in the new system. It was not possible to differentiate the changes caused by individual quarter pulsation and the new liners or differing pulsation ratio and frequency.

\section{CONCLUSIONS}

Holstein teat-end HK scores decreased after installation of an individual quarter pulsation milking system, which may reflect decreased overmilking. The results of this study indicate that individual quarter pulsation milking systems may decrease overmilking and reduce teat-end HK in Holstein cows. Teat-end HK did not improve in crossbred cows and actually increased in
Jersey cows over the study period. Differences between breeds may be attributed to differing teat size and shape between breeds. This multi-breed herd may have included too few Jerseys $(\mathrm{n}=9)$ and crossbreds $(\mathrm{n}=$ 12) to determine conclusions on the effects of individual quarter pulsation on teat-end HK for these particular breeds. Additional research is needed to determine if these results are applicable to varying herd conditions and larger herd numbers, and to understand the breed differences noted in this study. Changes in teat-end HK are not immediate and should be monitored over months. Although multiple factors affect teat-end health, milking systems play an integral part in maintaining smooth teat ends free of HK. Decreasing the incidence and severity of teat-end HK may decrease mastitis incidence; therefore, individual quarter pulsation milking systems may be beneficial to dairy producers and dairy cattle.

\section{ACKNOWLEDGMENTS}

The authors extend thanks to Milkline (Gariga di Podenzano, Italy) for donating the Milpro P4C milking system to the University of Kentucky. We appreciate the technical guidance and advice provided by Massimiliano Intini, Marco Cattaneo, and Pierandrea Conigliaro (all from Milkline). We also thank Barbara Wadsworth (University of Kentucky, Lexington) for her help calibrating the system. Finally, we express our extreme gratitude to Joey Clark, University of Kentucky Coldstream dairy manager, for maintaining the system.

\section{REFERENCES}

Breen, J. E., M. J. Green, and A. J. Bradley. 2009. Quarter and cow risk factors associated with the occurrence of clinical mastitis in dairy cows in the United Kingdom. J. Dairy Sci. 92:2551-2561.

Chrystal, M. A., A. J. Seykora, and L. B. Hansen. 1999. Heritabilities of teat end shape and teat diameter and their relationships with somatic cell score. J. Dairy Sci. 82:2017-2022. 
de Pinho Manzi, M., D. B. Nóbrega, P. Y. Faccioli, M. Z. Troncarelli, B. D. Menozzi, and H. Langoni. 2012. Relationship between teatend condition, udder cleanliness and bovine subclinical mastitis. Res. Vet. Sci. 93:430-434.

Gleeson, D. E., W. J. Meaney, E. J. O'Callaghan, and M. V. Rath 2004. Effect of teat hyperkeratosis on somatic cell counts of dairy cows. Int. J. Appl. Res. Vet. Med. 2:115-122.

Jacobs, J. A., and J. M. Siegford. 2012. Invited review: The impact of automatic milking systems on dairy cow management, behavior, health, and welfare. J. Dairy Sci. 95:2227-2247.

Mein, G. A., F. Neijenhuis, W. F. Morgan, D. J. Reinemann, J. E. Hillerton, J. R. Baines, L. Ohnstad, M. D. Rasmussen, L. Timms, J. S. Britt, R. Farnsworth, N. Cook, and R. Hemling. 2001. Evaluation of bovine teat condition in commercial dairy herds: 1 . Noninfectious factors. Pages 347-351 in Proc. 2nd Int. Symp. Mastitis and Milk Quality Vancouver, BC, Canada.

NOAA (National Oceanic and Atmospheric Administration). 1976. Livestock hot weather stress. US Dept. Commerce, Natl. Weather Serv. Central Reg. Operations Manual Lett. C31-76. NOAA, Kansas City, MO.

Natzke, R. P., P. A. Oltenacu, and G. H. Schmidt. 1978. Change in udder health with overmilking. J. Dairy Sci. 61:233-238.

Neave, F. K., F. H. Dodd, R. G. Kingwill, and D. R. Westgarth. 1969 Control of mastitis in the dairy herd by hygiene and management. J. Dairy Sci. 52:696-707.

Neijenhuis, F., H. W. Barkema, H. Hogeveen, and J. P. T. M. Noordhuizen. 2000. Classification and longitudinal examination of callused teat ends in dairy cows. J. Dairy Sci. 83:2795-2804.

Neijenhuis, F., H. W. Barkema, H. Hogeveen, and J. P. T. M. Noordhuizen. 2001a. Relationship between teat-end callosity and occurrence of clinical mastitis. J. Dairy Sci. 84:2664-2672.

Neijenhuis, F., G. A. Mein, J. S. Britt, D. J. Reinemann, J. E. Hillerton, R. Farnsworth, J. R. Baines, T. Hemling, I. Ohnstad, N.
Cook, W. F. Morgan, and L. Timms. 2001b. Evaluation of bovine teat condition in commercial dairy herds: 4 . Relationship between teat end callosity or hyperkeratosis and mastitis. Pages 362-366 in Proc. 2nd Int. Symp. Mastitis and Milk Quality, Vancouver, BC, Canada. National Mastitis Council, Madison, WI.

O'Shea, J. 1987. Machine milking and mastitis. Section 2: Machine milking factors affecting mastitis - A literature review. Bull. Int. Dairy Fed. 215:5-32.

Paduch, J.-H., E. Mohr, and V. Krömker. 2012. The association between teat end hyperkeratosis and teat canal microbial load in lactating dairy cattle. Vet. Microbiol. 158:353-359.

Rasmussen, M. D. 1999. Benefits from early removal of the milking unit. Pages 55-61 in Proc. Axient/Institute for Animal Health/ Milk Development Council. Novartis Animal Health, Stoneleigh, UK.

Rasmussen, M. D. 2004. Overmilking and teat condition. Pages 169 175 in NMC Annual Meeting Proc., Charlotte, NC. National Mastitis Council, Madison, WI.

Seykora, A. J., and B. T. McDaniel. 1985. Heritabilities of teat traits and their relationships with milk yield, somatic cell count, and percent two-minute milk. J. Dairy Sci. 68:2670-2683.

Seykora, A. J., and B. T. McDaniel. 1986. Genetics statistics and relationships of teat and udder traits, somatic cell counts, and milk production. J. Dairy Sci. 69:2395-2407.

Shearn, M. F. H., and J. E. Hillerton. 1996. Hyperkeratosis of the teat duct orifice in the dairy cow. J. Dairy Res. 63:525-532.

Zucali, M., D. J. Reinemann, A. Tamburini, and R. D. Bade. 2008 Effects of liner compression on teat end hyperkeratosis. Pages 1-5 in 2008 ASABE Annual International Meeting Proc., Providence, RI. American Society of Agricultural and Biological Engineers, St. Joseph, MI. 